\title{
Zone of Groundwater Quantitative Potential Based on the Characteristics of a Confined Aquifer at the Palu Groundwater Basin Central Sulawesi Province, Indonesia
}

\author{
Zeffitni $^{*}$, Muhammad Basir-Cyio ${ }^{*}$, Mery Napitupulu ${ }^{+}$ \\ \# Department of Civil Engineering, Tadulako University, Palu, 94118, Indonesia \\ E-mail: zefitni_04@yahoo.com \\ *Department of Agrotechnology, Tadulako University, Palu, 94118, Indonesia \\ E-mail: basircyio@gmail.com \\ ${ }^{+}$Department of Mathematics and Natural Science, Tadulako University, Palu, 94118, Indonesia \\ E-mail:merytn@gmail.com
}

\begin{abstract}
Groundwater is water stored in aquifers in a groundwater basin, which is influenced by geologic, hydrogeological, tectonic forces, and the structure of the earth. Increased water demand causes problems in water management, which are characterized by a decrease in water availability, especially groundwater. Groundwater resources are renewable, but refill time is relative, depending on water availability, surface conditions, rainfall, lithology, hydraulic conductivity, topography, groundwater level depth, and the influence of the nature of unsaturated zones. These conditions cause a decrease in groundwater availability. This phenomenon is also found in Central Sulawesi Province, especially at Palu Groundwater Basin. The distribution of groundwater potential, which has the spatial and temporal characteristics of the confined aquifer, has caused insufficient water supply at Palu Groundwater Basin. Thus, according to the problem, the research objectives are to analyze groundwater quantitative potential based on the characteristics of a confined aquifer on each hydro-morphology and the hydrogeology units of the aquifer. The study of the groundwater quantitative potential is based on spatial, geomorphologic, and geologic approaches, and is required to be done with survey methods, and analysis using Darcy's Law. The research result indicates that: The characteristic of a confined aquifer consists of an aquifer system in alluvial plains together with denudation. Based on the topographic relief variation conditions, including the structure of the material and geomorphic process, the lithology and stratigraphy that sort Palu Groundwater Basin consists of Alluvium and the Pakuli Formation with the lithology variation. Confined aquifers are big $(>10.0 \mathrm{l} / \mathrm{sec})$. The potency groundwater zone in the Palu Groundwater Basin is fluctuated greatly, ranging from high to medium. The groundwater potency based on a hydro-morphology at landform unit alluvial plains varies between medium to high potency.
\end{abstract}

Keywords - aquifer; basin; confined; groundwater

\section{INTRODUCTION}

Water problems are a global issue. In the world, more than 1.7 billion people live in watersheds. These people's use exceeds the flow of water flowing in the river, which leads to drainage of rivers, falling groundwater levels, and degradation of ecosystems. Two-thirds of the world's population will lack water in 2025 if consumption patterns like this continue to occur. Water demand is projected to increase by $55 \%$ by 2050 . Approximately $40 \%$ of city populations live in groundwater basins that overlap two or more countries, which account for around $60 \%$ of global freshwater flow. These conditions' are happening right now. Water reserves in Indonesia are estimated to reach
3,221 billion $\mathrm{m}^{3} /$ year, making this country one of the "wettest" countries in the world [4], [5].

Water is a significant factor in human life. Every day, it is estimated that people need a minimum of 100 liters of water / person, such as for drinking, cooking, bathing, washing, etc. Water potentials are the water resources that already exist today and those that meet the water needs for the future including agriculture activity [6], [10]. The impact of human activities in the hydrologic cycle and the quantitative estimates of water resources are essential and can be done by adsorption [7], [8], and water balance techniques [11], [12]. This water balance approach can be used to make a quantitative evaluation of water resources and its dynamic behavior under the influence of human activities [13]-[15]. 
It is argued that groundwater basins are a hydrogeological unit consisting of one or several parts of aquifers that are interconnected to form a system and can change due to changes in the environment [5], [16]. In other opinions [17], [18], it is explained that groundwater basins are an area with water originating from surface flow [19]. Groundwater basins are one example of a geomorphological system. The use of a geomorphological system is very appropriate to show the relationship between parts of a system in an object. Groundwater flow systems are influenced by several factors [20], [21]. Hubbert [22] added that groundwater flow is caused by potential differences in the fluid.

Groundwater is a vital natural resource for human activities that are extracted from the ground. The amount of water extracted without causing depletion in groundwater [23], depending upon the nature of the aquifer and the groundwater recharge [24]. Thus a quantitative measurement of space and time for groundwater recharge is a pre-requisite for the operating groundwater resources system [25], [26].The availability of water is increasingly limited every year both in quality and quantity, while the needs are increasing, including the need for drinking water [27]. Some of the things that affect water scarcity are population growth, agricultural extension, industrialization, residential expansion, and other demographic changes [28]. The catchment area is vital for water resource conservation, both in terms of quality and quantity [29].

The imbalance between supply and demand of groundwater is a complex problem of water management in the Palu area. The increasing of the population numbers and development of various sectors such as domestic, industrial, agriculture, and other industries in Palu directly or indirectly also require the increasing provision of groundwater. The optimal pumping in an aquifer is essential for determining the level of water exploitation from the hydrogeology source, but in fact, it is difficult to be determined if it does not consider the quantitative and qualitative of hydrogeology potential. This condition will be increased if accompanied by a mistaken understanding of the hydrogeology characteristics, as well as the impact on development and human activity [35].

It is argued that the degradation of surface water availability in Palu previously had a capacity of $15 \mathrm{l} / \mathrm{sec}$, now down to $10 \mathrm{l} / \mathrm{sec}$ [5]. The reduced flow of water in the river means that PDAM Palu city must rotate the distribution of water to customers. To meet the clean water needs of the Palu community, the PDAM must have a production installation with a capacity of $500 \mathrm{l} / \mathrm{sec}$. The study determines the zone of groundwater quantitative potential based on the characteristic confined aquifer in the Palu Groundwater Basin (Fig.1).

\section{MATERIAL AND METHOD}

Groundwater is water stored in aquifers in a groundwater basin, which is influenced by geologic, hydrogeological, tectonic forces and the structure of the earth. Increased water demand causes problems in water management, which are characterized by a decrease in water availability, especially groundwater [30].

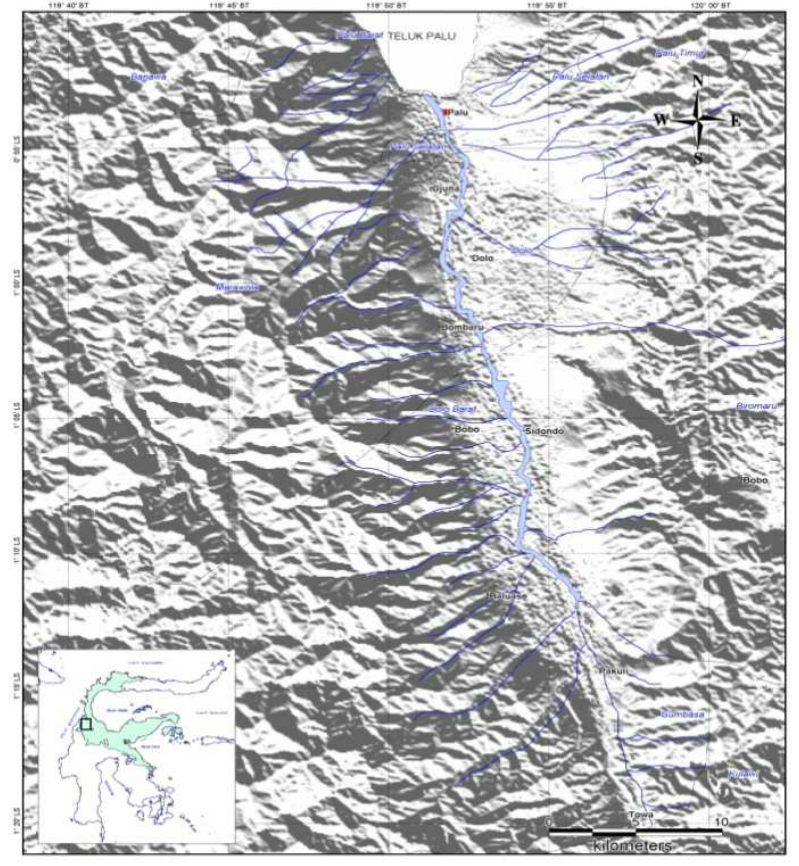

Fig 1. The Research area at Palu [30]

Groundwater resources are renewable, but refill time is relative, depending on water availability, surface conditions, rainfall, lithology, hydraulic conductivity, topography, groundwater level depth, and the influence of the nature of unsaturated zones [31]. Precipitation is the fundamental source of groundwater recharge, the amount of recharge depends upon the nature of rain, the duration it takes, the type of the soil, the antecedent soil moisture and usually the depth to the water table [33]. Recharge has been defined as the process of the addition of water to the saturated zone [32]. In [22], the limits are the hydraulic conductivity or the value of permeability, as well as the speed of water flowing into the soil. Permeability value is a function of porous media that has porosity, the level of relationship between texture and material sorting. Calculation of groundwater availability can be done by static or dynamic methods. If groundwater is considered stationary, then it can be calculated based on specific parameters, namely: the thickness of the aquifer, the particular yield according to the composition of the material making up the aquifer, and the area of each zone of potential groundwater. In fact, groundwater in aquifers flows at a certain speed, which means that groundwater is dynamic. Therefore, to calculate groundwater availability based on Darcy's principles (Fig.2).

$$
\mathrm{Q}=\mathrm{K} . \mathrm{I} . \mathrm{A} \text { or } \mathrm{Q}=\mathrm{T} . \mathrm{I} . \mathrm{L}
$$

Explanation:

Q: Debit $\left(\mathrm{m}^{3} /\right.$ day $)$

$\mathrm{K}$ : Permeability on average (m/day)

I : Hydraulic Gradient

I : dh/dl (ramps hydraulics)

A: Cross-sectional area of the aquifer $\left(\mathrm{m}^{2}\right)$

$\mathrm{T}$ : transmissibility $=\mathrm{KD}\left(\mathrm{m}^{2} /\right.$ day $)$

D: Aquifer thickness

L: Cross-section of the aquifer (m) 


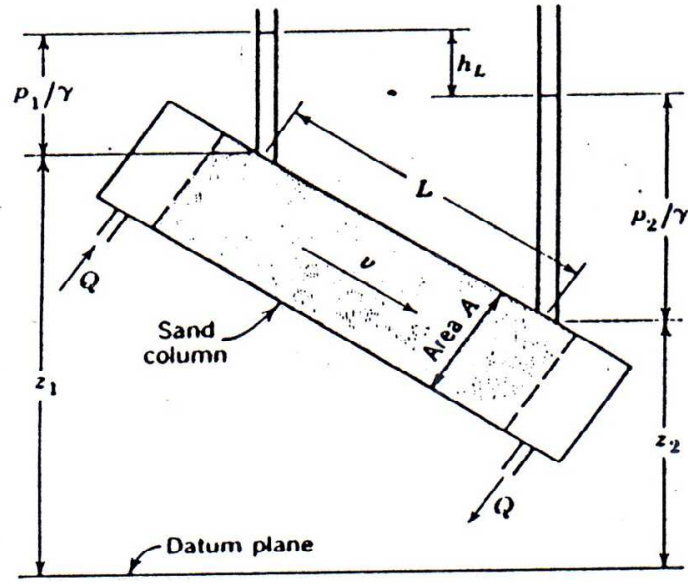

Fig 2. Darcy law [5]

Landform units generally affect groundwater distribution [34], [35]. The geomorphological approach to groundwater studies is to compile hydro-morphology maps [39]. The characteristics of aquifers are determined by the parameters and physical properties of the rocks that constitute the aquifers, namely: permeability, transmissibility, and yield of species. The quantitative potential of distressed groundwater is highly determined by type debit $\left(\mathrm{Q}_{\mathrm{s}}\right)$ and optimum discharge $\left(\mathrm{Q}_{\mathrm{opt}}\right)$. In [37], this goes from the concept that the type of Discharge is a debit that can reduce groundwater level per meter $(1 / \mathrm{sec} / \mathrm{m})$. Optimum discharge is a discharge that can reduce the groundwater level (drawdown $\left.n_{\text {opt }}\right) / \mathrm{m}$ with groundwater level $\left(\mathrm{PWL}_{\mathrm{opt}}\right) / \mathrm{m}$.

Data analysis in this research is based on survey results and primary data from several bore wells in each unit of landform in the Palu Groundwater Basin. Configuration of aquifer systems includes the determination of the lateral and vertical distribution of the aquifer and non-aquifer that have relatively similar hydraulic characteristics and are grouped into one aquifer system [38]. The aquifer configuration can be known from the hydrogeological cross-section and the determination of the upper and lower limits of the aquifer system. The depth of the upper limit of the depressed aquifer is critical to optimum discharge $\left(\mathrm{Q}_{\mathrm{opt}}\right)$. The drilling data in CAT Palu amounts to 78 wells, and only 23 wells have the pumping test data, namely 5 exploration drilling wells (SE) and 18 production drilling wells (SD) in Table 1.

TABLE I

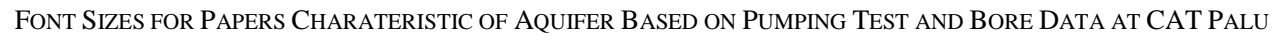

\begin{tabular}{|c|c|c|c|c|c|c|c|c|c|c|}
\hline \multirow[t]{2}{*}{ No } & \multirow{2}{*}{$\begin{array}{l}\text { Kode } \\
\text { Well } \\
\end{array}$} & \multirow[t]{2}{*}{ Location } & \multirow{2}{*}{$\begin{array}{l}\text { Elevati } \\
\text { (m wsl) }\end{array}$} & \multirow{2}{*}{$\begin{array}{c}\text { Dept } \\
\text { Well (m) }\end{array}$} & \multicolumn{4}{|c|}{ Characteristic of aquifer } & \multicolumn{2}{|c|}{ Geology } \\
\hline & & & & & K (m/day) & T ( $\mathrm{m}^{2} /$ day $)$ & Sy $(\%)$ & Qs (l/sec/m) & Litology & Formation \\
\hline \multicolumn{11}{|c|}{ I. East Aluvial Plain } \\
\hline \multicolumn{11}{|c|}{ District Biromaru } \\
\hline 1 & SE-TW-108 & Sidera & 13.6 & 65 & 65 & 559.8 & 56 & 6.8 & GRV.SND & Pakuli \\
\hline 2 & SE-TW-109 & Sidera & 13.7 & 65 & 67 & 647.5 & 56 & 0.4 & GRV.SND & Pakuli \\
\hline 3 & SD-DTW-110 & Souluwe & 17.8 & 105 & 47 & $3,452.0$ & 51 & 5.2 & SND.GRV & Pakuli \\
\hline 4 & SD-DTW-111 & Souluwe & 16.4 & 105 & 48 & $3,128,9$ & 51 & 8.2 & SND.GRV & Pakuli \\
\hline 5 & SD-DTW-112 & Watunonju & 21.5 & 105 & 68 & $1,067.9$ & 55 & 9.6 & SND.GRV & Pakuli \\
\hline 6 & SD-DTW-113 & Sidera & 17.8 & 105 & 67 & 649.7 & 56 & 2.1 & GRV.SND & Pakuli \\
\hline 7 & SD-DTW-114 & Bora & 15.6 & 105 & 49 & $1,238.0$ & 52 & 2.0 & GRV.CLY & Pakuli \\
\hline 8 & SD-DTW-115 & Bora & 14.5 & 102 & 43 & $3,478.0$ & 51 & 6.7 & GRV.CLY & Pakuli \\
\hline 9 & SD-DTW-120 & Sidera & 16.4 & 105 & 65 & 790.6 & 56 & 0.9 & GRV.SND & Pakuli \\
\hline 10 & SD-DTW-121 & Sidera & 21.5 & 105 & 65 & 329.0 & 58 & 0.4 & GRV.SND & Pakuli \\
\hline 11 & SD-DTW-122 & Souluwe & 14.5 & 105 & 49 & $4,517.0$ & 55 & 5.2 & GRV.SND & Pakuli \\
\hline 12 & SD-DTW-123 & Watunonju & 20.9 & 105 & 67 & $1,054.0$ & 52 & 1.2 & GRV.SND & Pakuli \\
\hline 13 & SD-DTW-124 & Bora & 15.6 & 105 & 47 & $3,162.0$ & 55 & 3.7 & SND.GRV & Pakuli \\
\hline 14 & SD-DTW-125 & Bora & 14.7 & 105 & 15 & $1,437.0$ & 31 & 8.6 & SND.CLY & Pakuli \\
\hline 15 & SD-DTW-126 & Bora & 15.3 & 105 & 15 & $7,114.0$ & 31 & 9.2 & SND.CLY & Pakuli \\
\hline 16 & SD-DTW-127 & Bora & 13.4 & 105 & 12 & $5,270.0$ & 30 & 6.1 & \begin{tabular}{|l} 
SND.CLY \\
\end{tabular} & Pakuli \\
\hline 17 & SD-DTW-128 & Bora & 15.2 & 105 & 48 & $9,034.0$ & 30 & 10.5 & SND.CLY & Pakuli \\
\hline 18 & SD-DTW-129 & Bora & 15.6 & 105 & 45 & $7,905.0$ & 30 & 2.3 & SND.CLY & Pakuli \\
\hline 19 & SD-DTW-130 & Bora & 14.8 & 105 & 45 & $2,964.5$ & 30 & 9.2 & SND.CLY & Pakuli \\
\hline 20 & SE-TW-131 & Bora & 16.3 & 105 & 68 & 12.4 & 55 & 0.0 & GRV.SND & Pakuli \\
\hline 21 & SE-TW-132 & Pombewe & 23.5 & 105 & 12 & 527.0 & 53 & 0.6 & SND.CLY & Pakuli \\
\hline 22 & SE-TW-133 & Lolu & 45.2 & 105 & 76 & 10.0 & 51 & 0.0 & GRV.SND & Aluvium \\
\hline \multicolumn{11}{|c|}{ II. West Aluvial Plain } \\
\hline \multicolumn{11}{|c|}{ District Marawola Kabupaten } \\
\hline 23 & SD-DTW-105 & Binangga & 34.0 & 105.0 & 57.0 & $4,350.9$ & 51.0 & 13.1 & SND.CLY & Aluvium \\
\hline
\end{tabular}




\section{RESULT AND DISCUSSION}

\section{A. Contour and Direction of Confined Aquifer Flow}

Based on the results of contour analysis and the direction of groundwater flow, that enters the Palu Groundwater Basin is calculated by the flownet. Conceptually, the pattern of the confined aquifer is relative to the topographic profile and geomorphological conditions and is mostly determined by the path of the rock being traversed. In order to get the correct value of electrical resistivity, it is needed to get the level of soil moisture. The electrical resistivity values from each treatment should be compared to electrical resistivity values of good lithology [24], [36].

Observations on confined aquifer systems are stressed on drill wells: exploration wells (SE) and production wells (SD) [36], [37. The results of contour and direction analysis of groundwater flow using the 2002 version of the Rockworks program. To be able to determine the possible quantitative level of the confined aquifer in the Palu Groundwater Basin, it is necessary to analyze: the contour and direction of groundwater flow are enclosed, the depth of the piezometric, and the depth of the upper limit of the confined aquifer.

Based on the data analysis, the depth of the upper limits of the confined aquifer in the eastern groundwater basin averaging 36.00 meters while in the western part, it averages $37.50 \mathrm{~m}$. The thickness of the upper limit of this distressed aquifer belongs to the moderate class $(20.00-50.00 \mathrm{~m})$ The Palu groundwater basin is grouped into 2 aquifer systems. The alluvial plain aquifer system is a potential primary aquifer, composed of coarse sand, fine sand, and clay. This aquifer system is dominated by a free aquifer with a thickness of $>83.24 \mathrm{~m}$ (Fig. 3, 4,5).

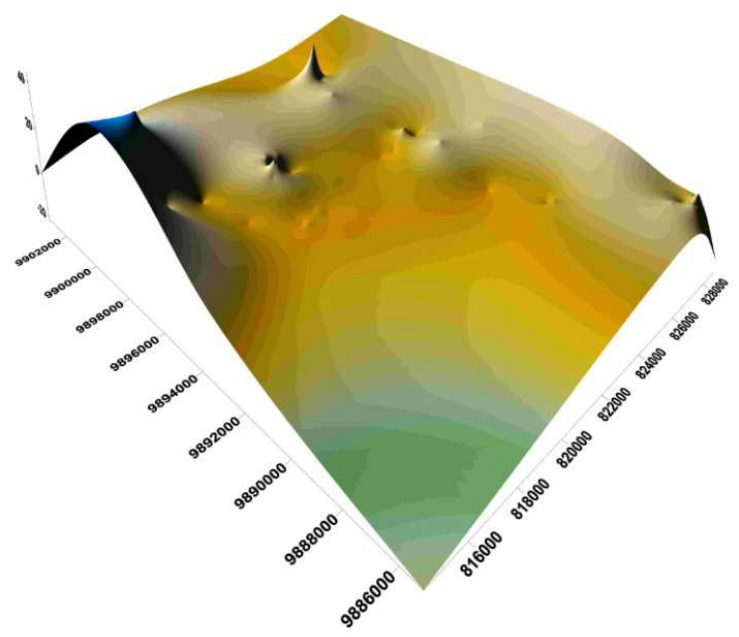

Fig 3. Piezometric level the Palu groundwater basin

\section{B. Depth of Piezometric of Confined Aquifer}

Based on the results of interpolation and analysis of field data, there is a correlation between geomorphological and geological conditions with confined aquifer depth [13]. In the Palu Groundwater Basin, the piezometric level ranges from shallow to deep. Shallow piezometric level $(<5.0 \mathrm{~m})$ distribution in eastern and western groundwater basins. On the east part of the groundwater basin in the District of East
Palu, the distribution is in the form of alluvial plains in the Alluvium Formation. The lithology of aquifer consists of gravel and clay sand. In the western part of the groundwater basin covers the sub-districts: South Palu and Marawola, with distribution on alluvial plains and floodplains, in the Alluvium Formation. The lithology of aquifer consists of gravel sand and clay-sand.

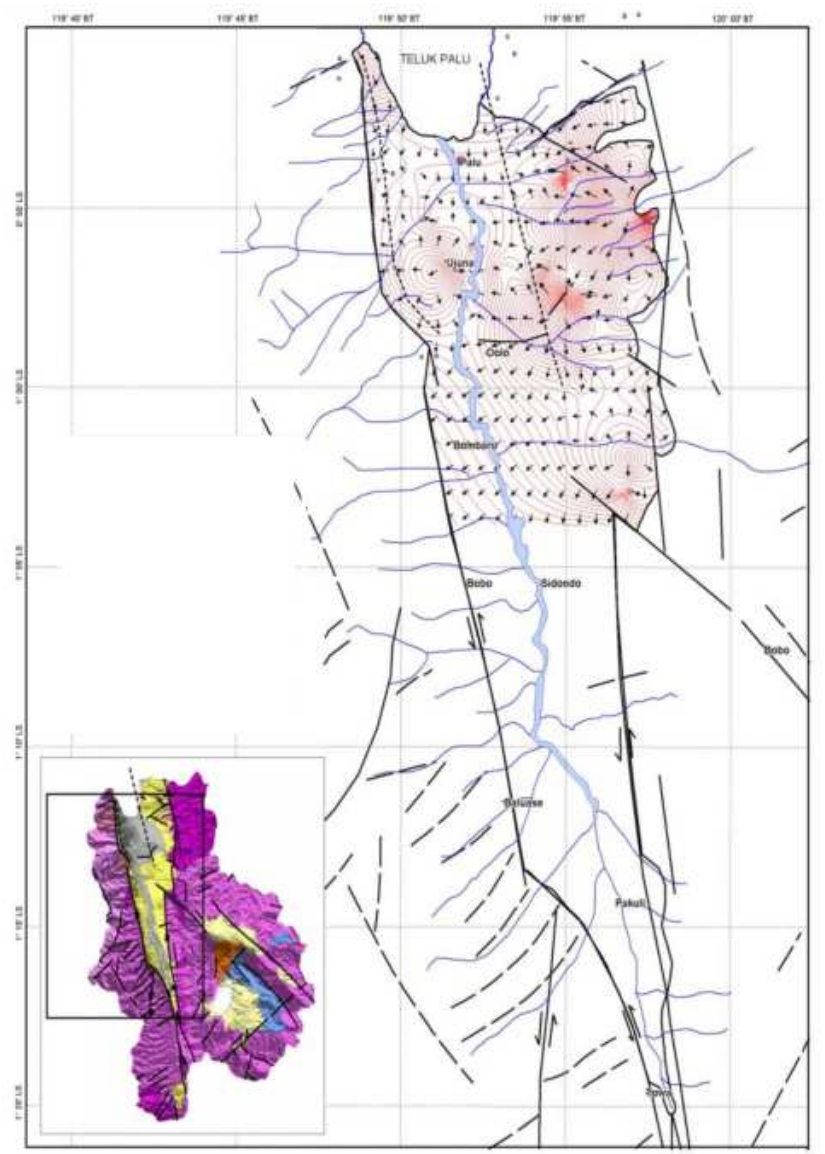

Fig 4. Map of contour and direction of confined aquifer flow of groundwater Palu basin

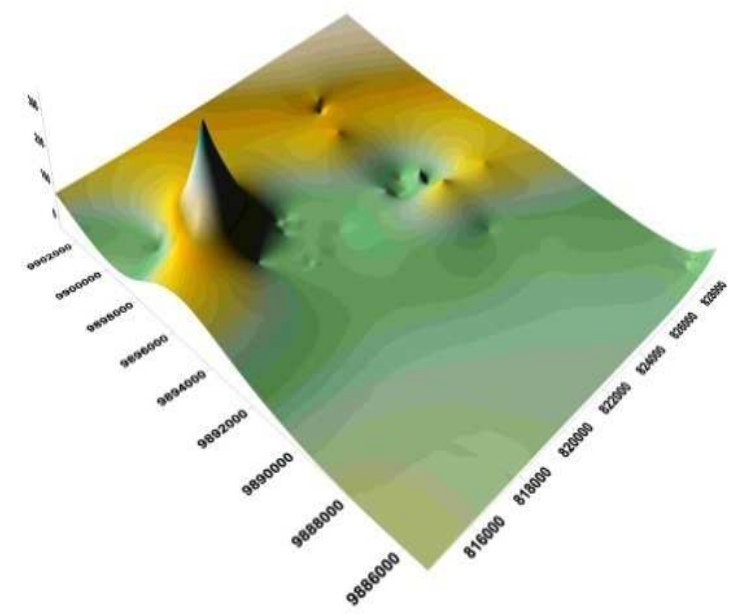

Fig 5. Hydraulic of confined aquifer in the Palu groundwater basin

In figure 4 , based on the geological conditions in the Alluvium Formation and Pakuli, the lithology making up aquifers consists of: gravel sand, clay sand, and sand gravel. 
This is in the western groundwater basin in the West Palu District, on the alluvial plains and denudation hills in the Alluvium and Pakuli Formations. The lithology of the aquifer consists of granodiorite and gravel sand.

In figure 5 and 6 , the deep of piezometric (> $10.0 \mathrm{~m}$ ) spread in the eastern and western groundwater basins. In the eastern groundwater basin, in the South Palu and Biromaru sub-districts, namely in the alluvial plains and floodplains, and in the denudation hills (Ngatabaru area).

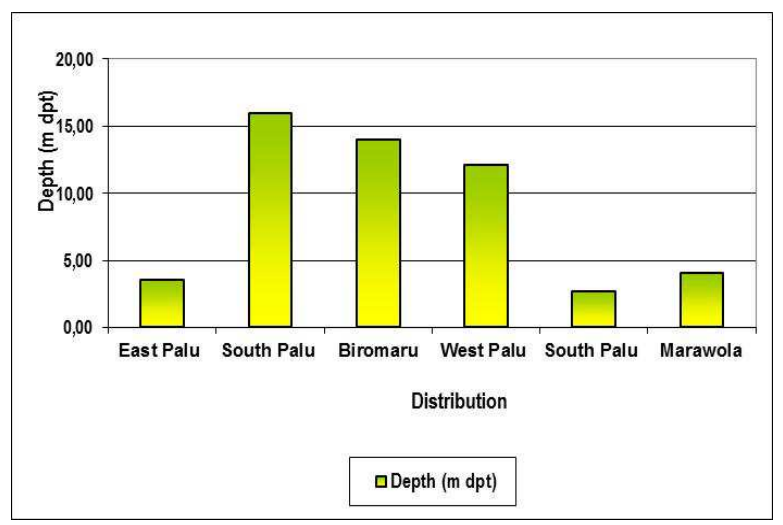

Fig 6. Graph of piezometric depth in the groundwater Palu basin

\section{Boundary Depths of Confined Aquifers}

The depth limit of the confined aquifer determines the optimum discharge. The depth limit of the confined aquifer is analyzed based on pumping test data. The number of bore wells in the Palu Groundwater Basin, is 78 bore wells, and is distributed in the eastern part of the groundwater basin, namely in the Districts of East Palu, South Palu and Biromaru.

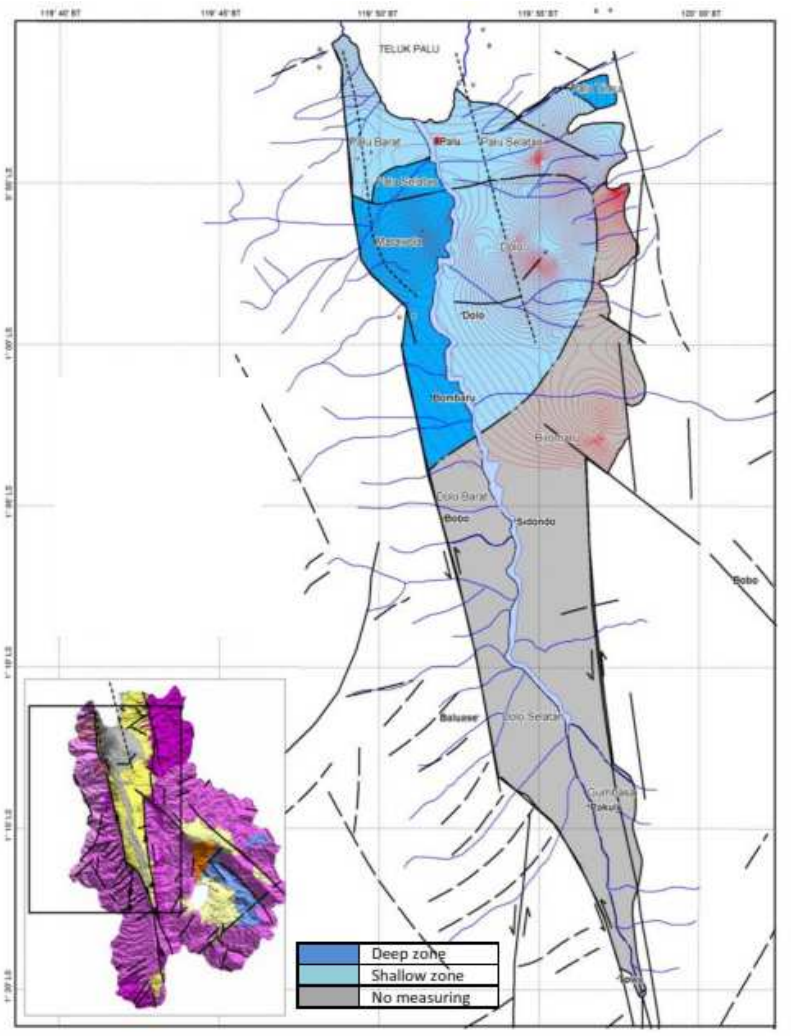

Fig 7. Map of piezometric zone in the Palu groundwater basin
In the west, namely in the Districts of West Palu, South Palu, and Marawola, the 78 drilling wells, only 23 wells have pumping test data, namely 5 exploration drill wells (SE) and 18 production drill wells (SD). Based on the results of data analysis, the depth of the upper limit of confined aquifers in the eastern groundwater basin is $61.30 \mathrm{~m}$ while in the west, the average is $62.25 \mathrm{~m}$. The thickness of the upper limit of the compressed aquifer is included in the class (> 50 m) (Fig.8).

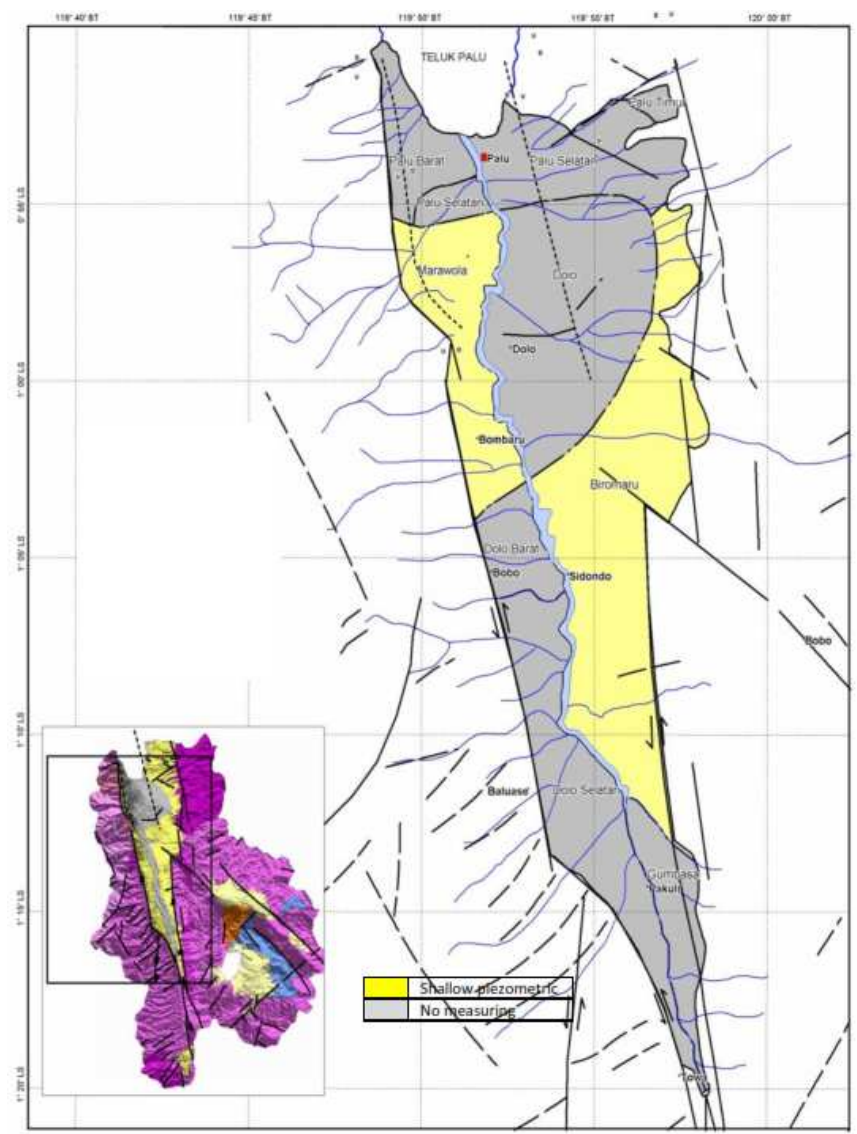

Fig 8. Map of depth zone confined aquifer in the Palu groundwater basin

\section{Level of Quantitative Potential of Confined Aquifer}

The results of the calculation and analysis of data show that in the Palu Groundwater Basin, the standard type of discharge is $4.86 \mathrm{l} / \mathrm{sec} / \mathrm{m}$. Type discharge with medium class, the distribution in the eastern groundwater basin is $4.49 \mathrm{l} / \mathrm{sec} / \mathrm{m}$. The delivery is in the District of Biromaru, in the form of alluvial plains, floodplains, and denudation hills, in the Formations of Alluvium and Pakuli.

Lithology composing aquifers: sandstone gravel, gravel sand, clay gravel, and clay sand. Debit types with a large class, the distribution in the western groundwater basin are $13.10 \mathrm{l} / \mathrm{sec} / \mathrm{m}$. The delivery is in Marawola Subdistrict, in the form of floodplain land in the Alluvium Formation with lithology composing aquifers: clay sand (Fig.9). The results of the calculation and analysis of the data show that in the Palu Groundwater Basin, the optimum discharge averages $54.241 / \mathrm{sec}$. 
Level of Quantitative Potential of Confined Aquifer in CAT Palu
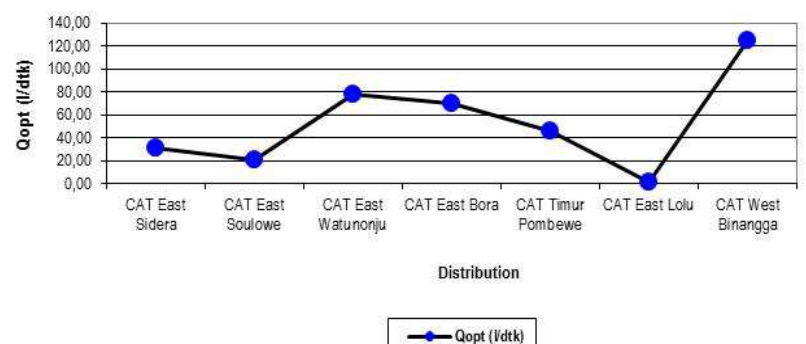

Fig 9. Level of quantitative potential of confined aquifer in the Palu groundwater basin

In the eastern groundwater basins, the average number is $51.02 \mathrm{l} / \mathrm{sec}$ and in the west, the average amounts to 124.90 $1 / \mathrm{sec}$. Based on the criteria of the reference and actual conditions in the field, the optimum discharge is classified as significant (> 10.0 1/sec) (Fig.10).

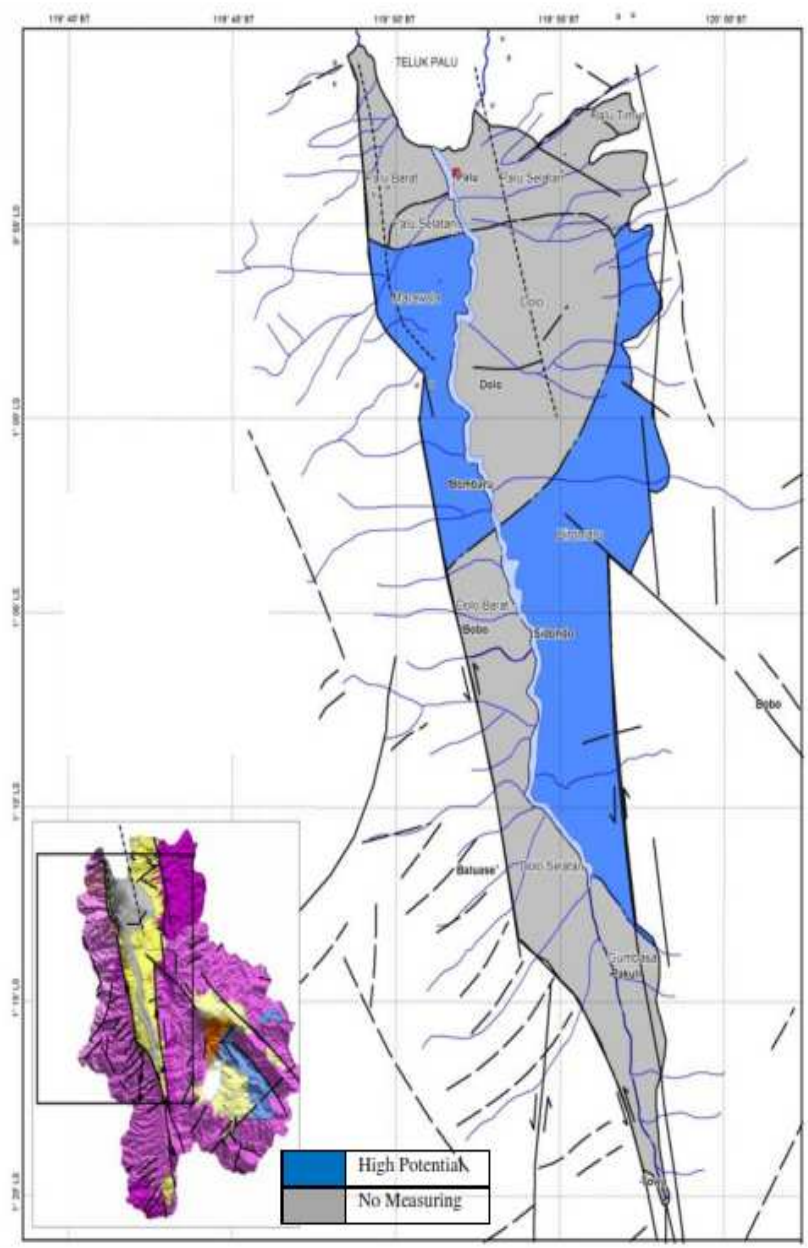

Fig 10. Map of zone of quantitative potential confined aquifer in the Palu groundwater basin

\section{CONCLUSION}

Configuration of aquifer system in the Palu Groundwater Basin consists of aquifer system alluvial plains and denudational hills. Lithology and stratigraphy that describes the Palu Groundwater Basin consists of Alluvium and Pakuli Formation with the lithology variation. Confined aquifer is big (> $10.01 / \mathrm{sec})$. The potency groundwater zone in the Palu
Groundwater Basin is very variable with its fluctuations ranging from high to medium. Groundwater potency based on a hydromorphology at the landform unit of alluvial plains is medium - high potency.

\section{ACKNOWLEDGMENT}

This article is part of the Research of National Strategies funded by DRPM - Kemenristekdikti in 2013 -2015. On this occasion, the team of researchers expressed their gratitude for the funding that has been provided so that the research can be completed.

\section{REFERENCES}

[1] Panno SV, Luman DE, "Characterization of cover-collapse sinkhole morphology on a groundwater basin-wide scale using lidar elevation data,." A new conceptual model for sinkhole evolution. Geomorphology, 318, pp.1-17. Oct 2018.

[2] Pham HV, Torresan S, Critto A, Marcomini A. "Alteration of freshwater ecosystem services under global change - A review focusing on the Po River basin (Italy) and the Red River basin (Vietnam)," Science of The Total Environment, 652:1347-65. Feb 2019

[3] Schmeller DS, Loyau A, Bao K, Brack W, Chatzinotas A, De Vleeschouwer F, et al, "People, pollution and pathogens - Global change impacts in mountain freshwater ecosystems," Science of The Total Environment, 622-623:756-63. May. 2018.

[4] Zeffitni, "Review of water privatization as a consequence of the cancellation of the water resources law No.7. 2004," Journal of Geography, vol. 14, no.1, pp.1-7, June. 2016.

[5] Zeffitni and A. Rusdin, "Pasigala regional community based drinking water supply system as anticipation of degradation of surface water supply in Palu City," Journal of Geography, vol.14, No.1, pp.59-64, June. 2017.

[6] Basir-Cyio M, Mahfudz, Takanobu Inoue, Alam Anshary, Tomori Kawakami, Nurdin Rahman, et al, "Impact of the traditional gold mine management on public health and agricultural land: A study of traditional gold mining in Poboya, Sausu and Dongi-Dongi village, central Sulawesi, Indonesia," Journal of Food, Agriculture and Environment, Institute for Environment and Development (LESTARI). vol.1;15(3-4), pp.115-22. July. 2017.

[7]. Mery Napitupulu, Daud K Walanda, Yoga Natakusuma, Muhammad Basir, Mahfudz, "Adsorption capacity of bio-charcoal from durian barks on cadmium (II) Ion," Journal of Surface Science and Technology, vol 34, no 1-2, pp.30-36. 2018.

[8] M Napitupulu, M Al-Gifary, DK Walanda, "Adsorption of Cd(II) by Carbon Prepared from Peels and Stems of Kepok Banana (Musa Paradisiaca Formatypica)," Journal of Cellulose Chemistry and Technology, vol.53, no.3-4, pp: 387-394. 2019.

[9] Dehghani M, Keshtgar L, Davoodi S, Shamsedini N, Zaravar F, "Data on the trend of corrosivity and scale formation potential of Shiraz groundwater drinking water resources during 2001-2007," Data in Brief. 23:103736. Apr 2019.

[10] Niu G, Zheng Y, Han F, Qin H, "The nexus of water, ecosystems and agriculture in arid areas: A multiobjective optimization study on system efficiencies," Agricultural Water Management. 223:105697. Aug. 2019.

[11] Makurira H, Savenije HHG, Uhlenbrook S, Rockström J, Senzanje A, "Investigating the water balance of on-farm techniques for improved crop productivity in rainfed systems: A case study of Makanya catchment, Tanzania," Physics and Chemistry of the Earth, Parts A/B/C. 34(1-2):93-8. Jan 2009.

[12] Peddinti SR, Kambhammettu BP, "Dynamics of crop coefficients for citrus orchards of central India using water balance and eddy covariance flux partition techniques," Agricultural Water Management. 212:68-77. Feb 2019.

[13] Zhang J, Zhang C, Shi W, Fu Y, "Quantitative evaluation and optimized utilization of water resources-water environment carrying capacity based on nature-based solutions," Journal of Hydrology. 568:96-107. Jan. 2019.

[14] H.Th. Verstappen and R.A.V. Zuidam, "System of Geomorphological Survey," Delf: ITC, 1968. 
[15] Zeffitni, "Water and sustainable development" Keynote Speaker in National Seminary, Medan Institute of Technology, August. 2015.

[16] D.K.Todd, Groundwater Hydrology. New York: John Willey and Sons, Inc, 1980.

[17] K.J. Gregory and D.E. Walling, Drainage Basin Form and Process. Norwich: Fletcher and Son Ltd, 1973.

[18] Zeffitni, "Groundwater potential in Groundwater Basin (CAT) Palu based on hydromorphology and hydrogeology unit," Journal of Geography, vol. 11, no.2, pp. 97-106, Dec. 2013.

[19] Ogawa Y, Ishiyama D, Shikazono N, Iwane K, Hoshino T, Kajiwara $\mathrm{M}$, et al. "Fractionation of rare earth elements (REEs) and actinides ( $\mathrm{U}$ and $\mathrm{Th}$ ) originating from acid thermal water during artificial and natural neutralization processes of surface waters," Geochimica et Cosmochimica Acta. 249:247-62. March.2019.

[20] Cao C-S, Shi Y, Xu H, Zhao B, "Metal-metal bonded compounds with uncommon low oxidation state," Coordination Chemistry Reviews. 365:122-44. June. 2018

[21] Erőss A, Csondor K, Izsák B, Vargha M, Horváth Á, Pándics T, "Uranium in groundwater - The importance of hydraulic regime and groundwater flow system's understanding," Journal of Environmental Radioactivity, 195:90-6. Dec.2018.

[22] C.W. Fetter, Applied Hydrogeology. $3^{\text {th }}$ edition. New York: Mac Millan Publishing Company, 1994.

[23] Jia X, O'Connor D, Hou D, Jin Y, Li G, Zheng C, et al, "Groundwater depletion and contamination: Spatial distribution of groundwater resources sustainability in China," Science of The Total Environment.672:551-62. Jul.2019.

[24] Sedghi MM, Zhan H, "Groundwater dynamics due to general stream fluctuations in an unconfined single or dual-porosity aquifer subjected to general areal recharge," Journal of Hydrology. 574:43649. Jul.2019

[25] M.G. Abdullahi, M.K.A Kamarudin, M.E. Toriman, M. B. Gasim, A. Endut, and I. Garba, "Assessment of natural groundwater recharge in Terengganu, Malaysia,” Int. J. Adv. Sci. Eng. Inf. Technol. vol. 6, no.5, pp. 781-786, 2016

[26] Zeffitni,"Public acces and government policy on drinking water infrastructure in City Palu Central Sulawesi Province. In Proc Bigstar, pp. 220 - 231. Oct. 2013.

[27] Ercin E, "Overuse of Water Resources: Water Stress and the Implications for Food and Agriculture," In: Encyclopedia of Food Security and Sustainability. Elsevier, pp.206-11. Available from: https://linkinghub.elsevier.com. [cited 2019 Oct 10].
[28] Brunner MI, Zappa M, Stähli M, "Scale matters: Effects of tempora and spatial data resolution on water scarcity assessments," Advances in Water Resources. 123:134-44. Jan. 2019.

[29] I.GST AG PT. Eryani, I. Lanya, I GST NGR Santosa, and I.N Norken, "Water potential in petanu river estuary and model of water resources management for sustainable agriculture in Gianyar regency Bali Province,” Int. J. Adv. Sci. Eng. Inf. Technol, vol. 4, no. 6, pp. 436-440, 2014.

[30] Zeffitni, "Spatial distribution of groundwater potetial at Palu Groundwater Basin, Central Sulawesi Province," Doctoral, Disertation, Gajah Mada University, April. 2010.

[31] Zeffitni, S. Lipu, and D.M. Mangitung, "Active participation P3A in management of irrigation network groundwater (JIAT) in regional areas of surface water at Central Sulawesi Province, Indonesia.," Int. J. Civ. Eng. Technol. vol 8, no. 5, pp.1161 -1169, Oct. 2017.

[32] N.A.A. Aziz, M.E. Toriman, M.B.Gasim, S. Muftah, A. Barggig, and M.K.A. Kamarudin, "Water quality deterioration in artificial lake: their impact and sources," Int. J. Adv. Sci. Eng. Inf. Technol, vol.7, no. 1, pp 49-56, 2017.

[33] N. Sari, M. Azwan, M. Zawawi, Prastowo, and Y Suharnoto, "Effects of soil moisture content on groundwater electrical resistivity values in irrigation paddy scheme, Tanjong Karang, Malaysia," Int. J Adv. Sci. Eng. Inf. Technol. vol. 4, no.5, pp 340-344, 2014.

[34] H.Th, Verstappen, Applied Geomorphology. Geomorphological Surveys for Environmental Development. New York: Elsevier Amsterdam Oxford, 1983

[35] Zeffitni, "Spatial ecological distribution of groundwater potency to domestic availability at Palu Groundwater Basin Central Sulawesi Province," Journal of Human and Environment. vol 19. no 2. pp: 105 - 117, July. 2012

[36] Zeffitni and A. Rusdin, "Spatial distribution of electerical conductivities model for detection on of groundwater vulnerability due to seawater intruction into Groundwater Basin in Palu City," in Proc. ICTIS, July. 2016, pp: 484-489.

[37] Zeffitni, "Identification lateral boundary of aquifer system Palu Groundwater Basin," in Proc. Redstar, June 2012, pp: 453-465.

[38]. Zeffitni, "Identification of lateral boundary Palu groundwater basin," Journal of SMARTEK. vol.9, No. 4. Pp: 337-349. Nov. 2011.

[39]. Zeffitni, "Groundwater potential based on groundwater characteristics in each hydromorphological unit in the Palu groundwater basin," Journal MEKTEK. Vol. XII. No.2, pp: 146-152. May. 2010. 